\title{
FIRST RECORD OF Micrasema cinereum Mosely (TRICHOPTERA, BRACHYCENTRIDAE) IN TURKEY AND A LIST OF THE CADDISFLY FAUNA IN ARAÇ CREEK
}

\author{
İbrahim KÜÇÜKBASMACI ${ }^{1 *}$, Özlem FINDIK ${ }^{2}$ \\ ${ }^{1}$ Kastamonu University, Sciences and Arts Faculty, Department of Biology, Kastamonu, TURKEY \\ ${ }^{2}$ Nevşehir Hacı Bektaş Veli University, Sciences and Arts Faculty, Department of Molecular Biology and Genetics, \\ Nevşehir, TURKEY \\ *Corresponding author: ORCID ID: orcid.org/0000-0002-9780-5002, e-mail: ikucukbasmaci@kastamonu.edu.tr
}

Cite this article as:

Küçükbasmacı İ., Fındık Ö. 2019. First Record of Micrasema cinereum Mosely (Trichoptera, Brachycentridae) in Turkey and a List of the Caddisfly Fauna in Araç Creek. Trakya Univ J Nat Sci, 20(2): 81-87, DOI: 10.23902/trkjnat.484166

Received: 16 November 2018, Accepted: 30 April 2019, Online First: 03 May 2019, Published: 15 October 2019

\begin{abstract}
Systematic studies on Trichoptera larvae in Turkey are very limited. The larval stage of the endemic species remains especially unknown. This study was carried out in Araç Creek between April and October 2013 and it is the first study to determine the caddisfly fauna in Araç Creek. Fourteen caddisflies taxa belonging to nine genera within eight different families (Brachycentridae, Hydropsychidae, Hydroptilidae, Lepidostomatidae, Leptoceridae, Limnephilidae, Psychomyiidae and Rhyacophilidae) were identified. Four of these taxa have previously been recorded from the creek and the other ten taxa are new records for the study area while Micrasema cinereum Mosely is the first record for the Trichoptera fauna of Turkey. As a result of the study, the number of caddisfly taxa in Turkey is now 501, with the addition of M. cinereum.
\end{abstract}

Key words: New record, larvae, description, benthic macroinvertebrates, Araç creek, Turkey.

Özet: Türkiye'de Trichoptera larvaları üzerindeki sistematik çalışmalar çok sınırlıdır ve özellikle endemik türlerin larva evresi bilinmemektedir. Çalışma Araç Çayı'nda 2013 yılı Nisan-Ekim ayları arasında gerçekleştirilmiştir ve Araç Çayı'nın Trichoptera faunasını belirleyen ilk çalışmadır. Sekiz farklı familyadan (Brachycentridae, Hydropsychidae, Hydroptilidae, Lepidostomatidae, Leptoceridae, Limnephilidae, Psychomyiidae ve Rhyacophilidae) 9 cinse ait 14 Trichoptera taksonu belirlenmiştir. Bu taksonlardan dördü daha önce Araç Çayı'ndan kaydedilmiş, diğer 10 takson ise Araç Çayı için yeni kayıttır. Buna ek olarak, Micrasema cinereum Mosely ise Türkiye Trichoptera faunası için ilk kayıttır. Çalışmanın sonucunda, Türkiye'deki Trichoptera takson sayısı yeni bir kayıtla birlikte 501 olmuştur.

\section{Introduction}

Brachycentridae larvae are characterized and distinguished from larval stages of other caddisfly families by (i) the absence of lateral and dorsal humps in the first abdominal segment, (ii) possessing transverse groove at midlenght of pronotum, (iii) a pair of plates (that are often divided longitudinally by narrow sutures) on mesotonum, and (iv) either the absence of primary setal area or the presence of sclerotized setae on metanotum (Flint 1984, Vieira-Lanero et al. 1998, Pescador et al. 1995). Larvae, in general, live in cold lotic fresh-water springs, streams and rivers while some species can also live in the shores of lakes, as in the case of the genus Micrasema McLachlan (Pescador et al. 1995). Micrasema consists of only 23 species in the West Palearctic Region fauna (Malicky 2004) and their larvae, whose inhabitant area is mostly surrounded by mosses and other plants, can resist and therefore inhabit shallow streams (Hilsenhof 1985). The caddisfly fauna of Turkey is represented by
500 taxa (461 species and 39 subspecies) (Darılmaz \& Salur 2015, Küçükbasmacı \& Kıyak 2017, Sipahiler 2016, Sipahiler 2017a, b, Sipahiler 2018a, b) Most of the studies on caddisflies have been performed based on their adults, but taxonomic studies on their larval stages are limited in Turkey. In particular, there is a lackabout descriptive studies on larvae of endemic species. The lack of taxonomic and ecological data on benthic macroinvertebrates has been concluded to negatively affect their reliable use in biomonitoring related studies in Turkey, and studies at species level on key taxons one of which is Trichoptera in addition to Ephemeroptera, Odonata, Plecoptera, Simuliidae and are believed to contribute to improvement of such studies (Kazanc1 \& Ertunç 2010). From this point of view, this study was performed in order to determine caddisfly fauna of Araç Creek (Kastamonu) as a contribution to Turkish caddisfly fauna. 


\section{Materials and Methods}

\section{Study area}

The study was performed in Araç Creek located in northern part of Turkey (Fig. 1). Araç Creek, originating from the northern slope of Ilgaz Mountains and passing through İhsangazi and Araç districts of Kastamonu province, merges with Soğanlı Creek to form Yenice River (Filyos River) with other tributaries. The creek is affected by various human activities including city sewage systems, organic wastes, agricultural activities, hydroelectric power plants and sand quarries. Macroinvertebrate samplings were performed at 6 stations along the creek in April, August and October 2013 (Fig. 1). The coordinates and altitudes of the sampling stations as well as sampling dates and short descriptions of the localities where the stations were selected are given in Table 1.

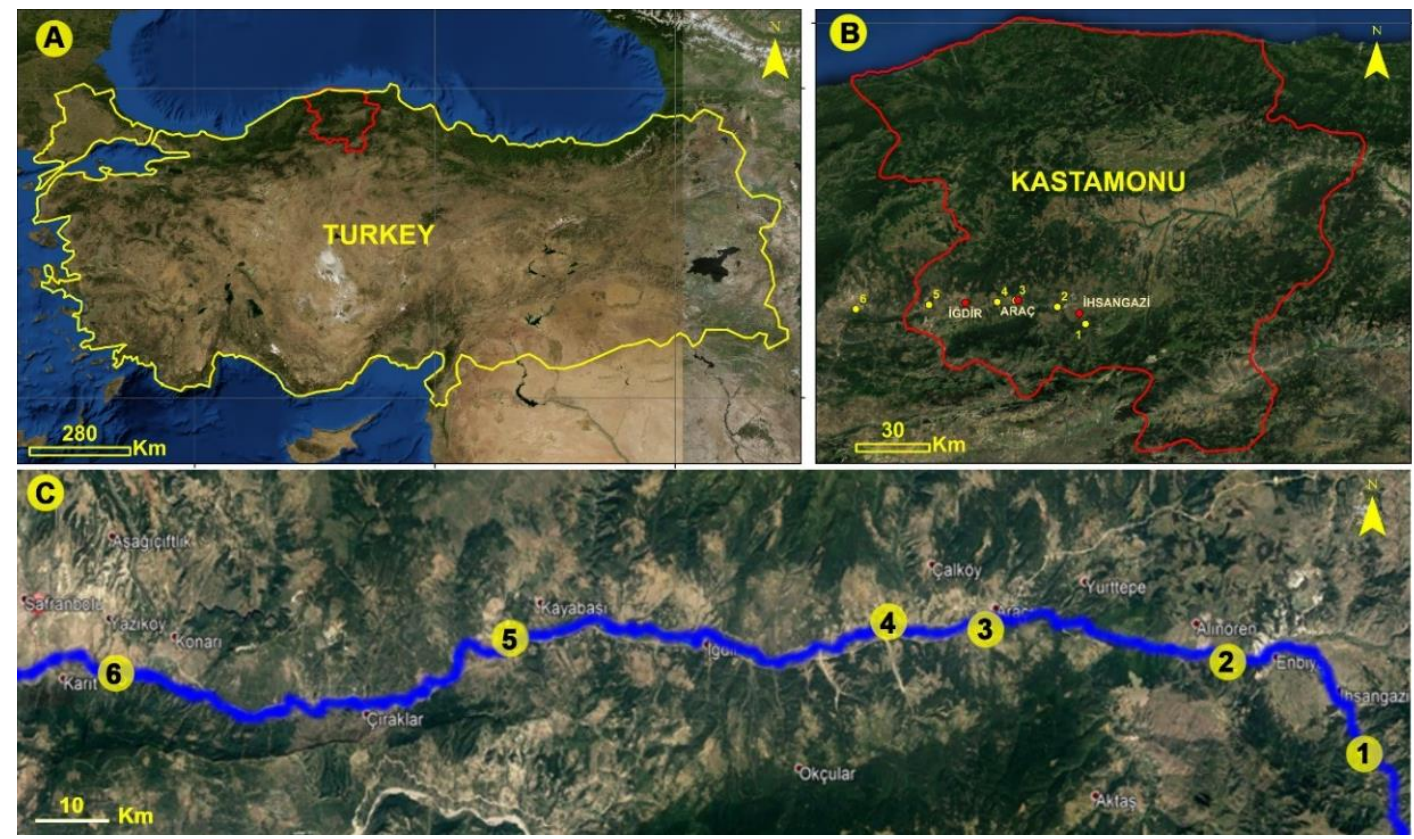

Fig. 1. (A) Map of Turkey. (B) The general view of study area. (C) Sampling stations in Araç Creek (Google Earth 2019). The numbers denote the stations whose details are given in Table 1.

Table 1. Details of the stations from where the samples were collected.

\begin{tabular}{|c|c|c|c|c|}
\hline $\begin{array}{l}\text { Station } \\
\text { No }\end{array}$ & $\begin{array}{c}\text { Sampling } \\
\text { date }\end{array}$ & Sampling station & Coordinate & $\begin{array}{l}\text { Altitude } \\
\text { (m) }\end{array}$ \\
\hline 1 & $\begin{array}{l}28.04 .2013 \\
15.08 .2013 \\
27.10 .2013\end{array}$ & $\begin{array}{l}\text { Kastamonu, İhsangazi, beyond } 1 \mathrm{~km} \text { from the Örencik } \\
\text { village road junction }\end{array}$ & $\begin{array}{l}41^{\circ} 10^{\prime} 39.60^{\prime \prime} \mathrm{N} \\
33^{\circ} 34^{\prime} 16.30^{\prime \prime} \mathrm{E}\end{array}$ & 920 \\
\hline 2 & $\begin{array}{l}28.04 .2013 \\
15.08 .2013 \\
27.10 .2013\end{array}$ & $\begin{array}{l}\text { Kastamonu, İhsangazi, İhsangazi-Araç road } 7^{\text {th }} \mathrm{km} \text {, } \\
\text { Akkaya village road junction, the bridge vicinity }\end{array}$ & $\begin{array}{l}41^{\circ} 13^{\prime} 6.70^{\prime \prime} \mathrm{N} \\
33^{\circ} 28^{\prime} 57.50^{\prime \prime} \mathrm{E}\end{array}$ & 784 \\
\hline 3 & $\begin{array}{l}28.04 .2013 \\
15.08 .2013 \\
27.10 .2013\end{array}$ & $\begin{array}{l}\text { Kastamonu, Araç, end of the Araç county, vicinity to } \\
\text { the gas station }\end{array}$ & $\begin{array}{l}41^{\circ} 14^{\prime} 21.13^{\prime \prime} \mathrm{N} \\
33^{\circ} 19^{\prime} 19.80^{\prime \prime} \mathrm{E}\end{array}$ & 632 \\
\hline 4 & $\begin{array}{l}28.04 .2013 \\
15.08 .2013 \\
27.10 .2013\end{array}$ & $\begin{array}{l}\text { Kastamonu, Araç, Araç-Karabük road } 7^{\text {th }} \mathrm{km} \text {, Tatlica } \\
\text { village road junction, the bridge vicinity }\end{array}$ & $\begin{array}{l}41^{\circ} 14^{\prime} 8.76^{\prime \prime} \mathrm{N} \\
33^{\circ} 15^{\prime} 21.67^{\prime \prime} \mathrm{E}\end{array}$ & 594 \\
\hline 5 & $\begin{array}{l}28.04 .2013 \\
15.08 .2013 \\
27.10 .2013\end{array}$ & $\begin{array}{l}\text { Kastamonu, Araç, Araç-Karabük road } 26^{\text {th }} \mathrm{km} \text {, } \\
\text { Yeşilova village }\end{array}$ & $\begin{array}{l}41^{\circ} 13^{\prime} 52.24^{\prime \prime} \mathrm{N} \\
33^{\circ} 00^{\prime} 22.95^{\prime \prime} \mathrm{E}\end{array}$ & 432 \\
\hline 6 & $\begin{array}{l}28.04 .2013 \\
15.08 .2013 \\
27.10 .2013\end{array}$ & Karabük, Safranbolu, Navsaklar village & $\begin{array}{l}41^{\circ} 12^{\prime} 56.85^{\prime \prime} \mathrm{N} \\
32^{\circ} 44^{\prime} 14.81^{\prime \prime} \mathrm{E}\end{array}$ & 301 \\
\hline
\end{tabular}




\section{$\underline{\text { Sampling method }}$}

Benthic macroinvertebrates in each station were collected between the stones, pebbles and plants on the ground using a standard dip net with a transecting area of $100 \mathrm{~m}^{2}$. Each sampling lasted 5 minutes. All samples were fixed in $80 \%$ ethanol immediately after collection, and then taken to the laboratory. The sampled material was investigated in the laboratory under a binocular stereomicroscope (Leica APO S8) and caddisfly larvae among the collected macroinvertebrates were transfered into tubes containing fresh $80 \%$ ethanol. The study material is deposited in the Entomology Laboratory of Biology Department of Faculty of Sciences and Arts, Kastamonu University, Turkey.

\section{Identifications of the caddisflies}

Caddisfly species, based on larvae, were identified under the binocular stereomicroscope using Trichoptera Families 2007 and Trichoptera 2005 package programmes (Lechthaler \& Stockinger 2005, Lechthaler 2007) and literature (Brohmer 1979; Edington \& Hildrew 1981, 1995; Hickin 1942, 1943, 1948, 1952, 1954, 1967, Ulmer 1909, Zamora-Muñoz et al. 1995). A general knowledge of morphological structures associated with caddisfly larvae is necessary for ease of identification. The head is dorsally divided by a Y-shaped ecdysial line referring to the frontoclypeal and coronal sutures, the frontoclypeus is bordered laterally by the frontoclypeal sutures, and the parietals extend posteromesally along the coronal suture. The anterolateral portion of the head contains the eyes and antennae, whose locations vary among the families. Mouthparts are among the essential structures for the identification of larvae, which include the labrum and labium that contain mandibles and maxillae. The position and view of these parts carry distinctive characteristics at family or genus levels. The posterior portion of the head often has a number of muscle scars which appear as dark or light spots. The shape and structure of the thorax segments are also important for identification of the larvae. The thorax segments -prothorax, mesothorax and metathorax- contain a dedicated pair of legs that are often a sclerotized notum. The prothorax generally has a fingerlike prosternal horn and a lateral pair of trochantins, which can be distinctive for several families. The prothorax is always covered by dorsal sclerotized plates while the meso- and metathorax do not always have sclerotized notal plates but possess notal subdivisions. Setae, if arising on the meso- or metanota, reside in characteristic areas termed setal area 1 (sa1), setal area 2 (sa2) and setal area 3 (sa3). Arrangement of both setal areas and sclerites can be of taxonomic importance. Thoracic legs have a tarsal claw apically. Each tarsal claw usually has a basal seta, the size of which can be of taxonomic value. The first abdominal segment often bears a dorsal hump and a pair of lateral humps, which provide circulation of water through the case as well as in securing the larva in the case. Some families have abdominal segments with numerous tracheal gills that facilitate gas exchange. The tracheal gills may be single or more filamentous, finger- like, comb-like, etc. The shape of the abdominal gills provide important taxonomic characters in diagnosis. Each of the anal prolegs has an anal claw, which can be simple or complex, that bear accessory spines. The anal prolegs, in terms of sclerites and nature and extension of setation, vary from family to family in degree of separation from the body. The case structure and form are among the distinguishing characters for the larvae of caddisflies. Some larvae have a case while others can survive without. The case can be made out of a variety of materials including sand grains, small pebbles, vegetal fragments and secretions. The shape of the larval case and the type of the materials used are utilized for taxonomic characterization.

\section{Results}

A total of 1223 larvae belonging to the order of Trichoptera were collected from the Araç Creek. 14 taxa belonging to nine genera within eight families (Brachycentridae, Hydropsychidae, Hydroptilidae, Lepidostomatidae, Leptoceridae, Limnephilidae, Psychomyiidae and Rhyacophilidae) were identified (Table 2). The systematic list of the identified trichopterans is given in Table 2. Among the determined taxa Micrasema cinereum is the first record for Trichoptera fauna of Turkey.

Morphometric, biological and ecological characteristics and the distribution of new record for the fauna of Turkey are as follows:

\section{Brachycentridae Ulmer}

Micrasema cinereum Mosely, 1930

\section{Description of the larva}

Materials examined: 1 larva, (Station 1); 1 larva, (Station 2).

Head capsule: Mean head width $0.67 \mathrm{~mm}$, mean head length $0.7 \mathrm{~mm}$. Head round (Fig. 2A); chestnut in color with Y-shaped patterned in yellowish along dorsal ecdysial line.

Head with a dorsolateral supraocular ridge are clear on each side, and one extra lateral infraocular ridge present that is shorter and less conspicuous. The frontoclypeal apotome (Fig. 2A) follows broadening view from the starting point.

Profile view of the head capsule (Fig. 2B) has a curved dorsal edge view. Periocular area is light yellowish. Ventral side of the head capsule (Fig. 2C) has similar color-toned to dorsum; ventral apotome is more of rectangular viewed with a narrowing end towards the anterior section that separates the genae completely. Sclerites of cardo brown in color, median margin with a slightly sharp anterior process. Submental sclerites have extended view, possessing seta as the ventral side of the head along with possessing long seta on each (Fig. 2C).

Legs (Figs. 2D, E, F) have same but paler colored as seen for meso- and metanotum. Prothoracic legs are 
shorter and stouter (Fig. 2D). Meso- and metathoracic legs are approximately same in size (Fig. 2E, F). Distal part of tibia of leg II and leg III show thin small tubercles (Fig. $2 \mathrm{G})$. Tarsal claws of 3 legs have similar structure.

Thorax (Fig. 2H): One half of the posterior pronotum is uniformly brown, and anterior section is obviously paler. Pronotum has an obvious curved transverse ridge view, one half of anterior and ridge does not show sparse view. Mesonotum has greenish islands in brown colored surface while the metanotum has bluish view. Tergite on each half of mesonotum is consisting of one single plate with the total number of tergite plates 2 (Fig. 2H). Metanotum is membranous, and has 2 pairs of small sclerites.
Abdomen is nearly cylindrical and posterior section is gradually tapered while segment IX is clearly thinner (Fig. 2K). Dorsal hump is absent and lateral humps are indistinct in segment I. Abdominal gills and lateral lines are absent.

Mid dorsal sclerite of segment IX (Fig. 2I) is weakly sclerotized, elliptical, with $c a$. 12 setae that are different in size along posterior margin.

Anal prolegs (Fig. 2I) are nearly sclerotized at dorsal view. Lateral sclerite is strongly sclerotized at dorsal view. Anal claw is stout and with 3 accessory hooks (Fig. $2 \mathrm{~J})$, for which one of them is poorly developed and often unobtrusive.
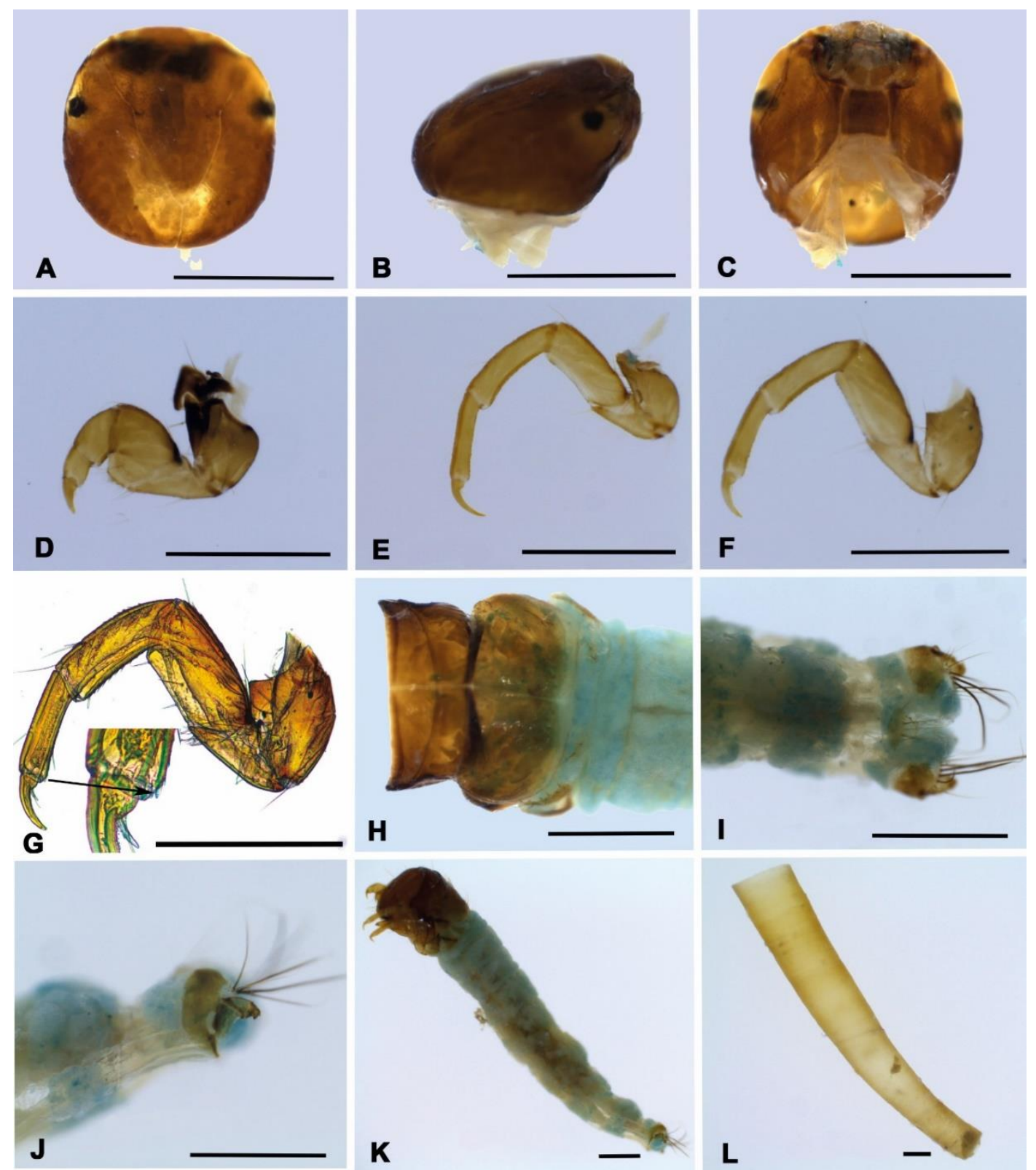

Fig. 2. Larva and case of M. cinereum (A) Head in dorsal view, (B) Head in lateral view, (C) Head in ventral view, (D) Prothoracic leg, (E) Mesothoracic leg, (F) Metathoracic leg, (G) Distal part of tibia of leg II and leg III, (H) Thorax in dorsal view, (I) $9^{\text {th }}$ abdominal segment and anal prolegs in dorsal view, (J) $9^{\text {th }}$ abdominal segment and anal prolegs in lateral view, (K) Larvae in lateral view, (L) Case in lateral view. Scale bars: $0.5 \mathrm{~mm}$. 
Table 2. Trichopteran taxa identified from the Araç Creek.

\begin{tabular}{|c|c|c|c|c|c|c|c|c|}
\hline \multirow{2}{*}{ Family } & \multirow{2}{*}{ Taxa } & \multirow{2}{*}{$\begin{array}{c}\text { Number of } \\
\text { larvae }\end{array}$} & \multicolumn{6}{|c|}{ Sampling Station } \\
\hline & & & 1 & 2 & 3 & 4 & 5 & 6 \\
\hline \multirow{2}{*}{ Rhyacophilidae } & Rhyacophila nubila Zetterstedt & 13 & * & * & & & * & \\
\hline & Rhyacophila sp. & 2 & & $*$ & & & & * \\
\hline Hydroptilidae & Hydroptila sp. & 3 & & & & & * & \\
\hline Psychomyiidae & Psychomyia pusilla (Fabricius) & 4 & & & & & $*$ & * \\
\hline \multirow{6}{*}{ Hydropsychidae } & Cheumatopsyche lepida (Pictet) & 4 & & & & $*$ & * & \\
\hline & Hydropsyche botosaneanui Marinkovic-Gospodnetic & 665 & $*$ & $*$ & * & * & * & $*$ \\
\hline & Hydropsyche bulbifera McLachlan & 250 & $*$ & * & * & * & $*$ & * \\
\hline & Hydropsyche exocellata Dufour & 93 & & & & * & * & * \\
\hline & Hydropsyche instabilis (Curtis) & 64 & & $*$ & $*$ & * & & \\
\hline & Hydropsyche pellucidula & 119 & $*$ & & $*$ & $*$ & $*$ & * \\
\hline Brachycentridae & Micrasema cinereum & 2 & $*$ & $*$ & & & & \\
\hline Lepidostomatidae & Lepidostoma hirtum (Fabricius) & 2 & & $*$ & & & & \\
\hline Limnephilidae & Limnephilus lunatus Curtis & 1 & & & & & $*$ & \\
\hline Leptoceridae & Setodes viridis (Fourcroy) & 1 & & & & & $*$ & \\
\hline
\end{tabular}

Table 3. The zoogeographical distribution of trichopteran taxa in Araç Creek. WP; West Palearctic, EP; East Palearctic, OL; Oriental, NA; Nearctic (Morse, 2018).

\begin{tabular}{llc}
\hline \hline \multicolumn{1}{c}{ Family } & \multicolumn{1}{c}{ Taxa } & Zoogeographical distribution \\
\hline \hline Rhyacophilidae & Rhyacophila nubila & EP and WP \\
& Rhyacophila sp. & - \\
\hline Hydroptilidae & Hydroptila sp. & WP \\
\hline Psychomyiidae & Psychomyia pusilla & EP and WP \\
Hydropsychidae & Cheumatopsyche lepida & EP and WP \\
& Hydropsyche botosaneanui & WP \\
& Hydropsyche bulbifera & WP \\
& Hydropsyche exocellata & WP \\
& Hydropsyche instabilis & EP, WP, NA and OL \\
\hline Brachycentridae & Hydropsyche pellucidula & WP \\
\hline Lepidostomatidae & Micrasema cinereum & EP and WP \\
\hline Limnephilidae & Lepidostoma hirtum & WP \\
\hline Leptoceridae & Limnephilus lunatus & EP and WP \\
\hline \hline
\end{tabular}

Body (Fig. 2K) length up to $3.6 \mathrm{~mm}$, mean body width up to $0.5 \mathrm{~mm}$.

Case (Fig. 2L) is about $6.9 \mathrm{~mm}$ long with yellow to orange color. It has a narrowing tubular shape from anterior to posterior with a curved ending (1/3 of the size). The case is made of secretion by the larvae.

\section{Habitat and distribution}

Giudicelli \& Orsini (1987) reported that M. cinereum inhabit one of the 3 sub-branches of Restonica river (Corsica), whose altitute is between 400-800 m. Décamps (1970) reported the presence of $M$. cinereum in low- and mid-altitudes of the rivers in moutainous areas, where $M$. longulum McLachlan, and M. minimum McLachlan were also found. We sampled $M$. cinereum at the proximity of the spring, where altitudes were recorded as 920 and 784 $\mathrm{m}$ for the stations 1 and 2 , respectively. Station 1 resembles the area described elsewhere (Décamps 1970) and is located $1 \mathrm{~km}$ south of İhsangazi in a place relatively far from the settlements in the forest area. The depth is approximately $30 \mathrm{~cm}$ with sediment mostly composed of rubbles and pebbles that are $2-20 \mathrm{~mm}$ in size. Station 2 , with a similar flow and habitat pattern as Station 1, is located at the $7^{\text {th }} \mathrm{km}$ of Kastamonu, İhsangazi, İhsangaziAraç road, Akkaya village road junction, in the bridge vicinity. The depth is approximately $25-30 \mathrm{~cm}$ and with a base structure mostly composed of small rocks.

The distribution range of $M$. cinereum has been given from France (Corsica) and Spain (Mosely 1930, Décamps 1970, García de Jalón 1982, Casado et al. 1990).

From the zoogeographical point of view, the Trichoptera fauna of Turkey is strongly related to the European fauna. The Trichoptera fauna of northeastern 
Turkey is related to the Caucasian/Transcaucasian fauna. The zoogeographical evaluation of caddisfly taxa in Araç Creek showed that $6(42,85 \%)$ species belong to West Palearctic, $5(35,71 \%)$ species belong to East-West Palearctic, and $1(7,14 \%)$ species belongs to East-West Palearctic, Nearctic, and Orientalic (Table 3). The zoogeographic distribution of the two taxa which were identified as Rhyacophila sp. and Hydroptila sp. are not shown here.

\section{Discussion}

The present study has been performed as the first study aiming to determine the Trichoptera fauna in Araç Creek where 14 caddisfly taxa were identified (Table 2). The sampled material was found to be represented with 12 species while two taxa could be identified at genus level. Rhyacophila $s p$. is different from $R$. fasciata Hagen with that the muscle attachment spots within the dark triangular patch on the frontclypeus are paler than the surrounding pattern and clearly discernible. Besides, it is different from $R$. nubila Zetterstedt by possessing the dark pattern on frontclypeus that is not extended to the anterior margin. Although it may seem different from the previously recorded $R$. nubila and $R$. fasciata, identification of the species was confined to genus level of the Rhyacophila $s p$. samples due to the fact that the diagnostic characters were not completely clear in our samples. Hydroptilidae family is distinguished from other caddisfly families with its characteristic life cycle where the first four larval instars live freely without having case while the fifth larval instar builds a case to live in. Case type and the construction material are distinguishing parameter among Hydroptilidae members (Pescador et al. 1995). The Hydroptilidae larvae were not at their $5^{\text {th }}$ instar, where the taxonomic characters are not clear enough, and we therefore preferred to use Hydroptila $s p$.

Although $M$. cinereum has been given as an endemic species from Corsica (Décamps 1970, Giudicelli \& Orsini 1987, Botosaneanu \& González 2006), its presence in Spain was also reported (García de Jalón 1982, Casado et al. 1990). According to the inventory given by Darılmaz \& Salur (2015), three species of genus Micrasema (Micrasema anatolicum Botosaneanu, M. bifoliatum Martynov and M. mencilis Sipahiler) have been reported from Turkey. However, the larval stages of these three species are not known, because these species were reported as adult samples.

Micrasema cinereum, which is distinguished from the other species with the following key characteristics is

\section{References}

1. Botosaneanu, L. \& González, M.A. 2006. Un difficile problème de taxonomie: les Micrasema (Trichoptera: Brachycentridae) des eaux courantes de la Péninsule Ibérique et des Pyrénées. Annales de la Société entomologique de France, 42(1): 119-127.

2. Brohmer, P. 1979. Fauna von Deutschland Ein Bestimmungsbuch unserer heimischen Tierwelt. Quelle and Meyer, Heidelberg, 167 pp. given as a new record in this study. Micrasema cinereum and $M$. longulum possess fully secretion-based case structures which is not seen in other Micrasema species. The case is constructed from natural minerals for $M$. moestum (Hagen) and M. minimum. In contrast to this, the case is made of plant materials for $M$. tristellum McLachlan and M. togatum (Hagen) and of plant material and secretion for M. morosum (McLachlan). Structurally, the case of $M$. cinereum and $M$. longulum has curving view at posterior side (Décamps 1970). The structural characteristic of mesothorax is one of the key parameters used to distinguish these species. Micrasema minimum, $M$. setiferum (Pictet) and $M$. moestum have four sclerotized plates. In contrast to this, M. longulum, $M$. cinereum, M. difficile Mosely, M. tristellum, M. togatum and $M$. morosum possess two sclerotized plates (Decampas 1970; Vieira-Lanero et al. 1998). The distal point of the tarsial ventral side of meso- and metathoraxic legs possess conic tubercles in M. longulum, which are thinner for $M$. cinereum. While mesothorax has two chitinized plates with latero-anterior angles that are extending forward, those are not present in M. cinereum. Mesotonum is slightly less-colored in plain brown for $M$. cinereum in comparison to $M$. longulum. Dorsal view of cephalic capsule possesses protuberances in the eyes for M. longulum (Décamps 1970) while the protuberances are absent for $M$. cinereum.

\section{Conclusion}

In conclusion, 14 taxa belonging to nine genera within eight families (Brachycentridae, Hydropsychidae, Hydroptilidae, Lepidostomatidae, Leptoceridae, Limnephilidae, Psychomyiidae, Rhyacophilidae) were identified in six stations along Araç Creek. Rhyacophila nubila, P. pusilla, H. bulbifera and $H$. pellucidula have previously been recorded in the creek by Küçükbasmacı \& Kiyak (2017), while Rhyacophila sp., Hydroptila sp., C. lepida, H. botosaneanui, H. exocellata, H. instabilis, $M$. cinereum, L. hirtum, L. lunatus and $S$. viridis are new records for the creek. Among M. cinereum was recorded for the first time in Turkey. The present records increased the number of caddisflies taxa in Turkey fauna to 501 .

\section{Acknowledgement}

This study was financially supported by Kastamonu University, Scientific Research Projects Coordination Department (project number KUBAP-01/ 2012-10). We authors thank Bilgehan Bilgili Library of Kastamonu University for their service in translating the article into English.

3. Casado, C., Montes, C. \& García de Jalón, D. 1990. Contribución al estudio faunístico del bentos fluvial del río Lozoya (Sierra de Guadarrama, España). Limnetica, 6: 87100 .

4. Darılmaz, M.C. \& Salur, A. 2015. Annotated catalogue of the Turkish caddisflies (Insecta: Trichoptera). Munis Entomology \& Zoology, 10(Suppl.): 521-734. 
5. Décamps, H. 1970. Les larves de Brachycentridae (Trichoptera) de la faune de France. Taxonomie et ecologie. Annales de Limnologie, 6: 51-73.

6. Edington J.M. \& Hildrew A.G. 1981. A Revised Key to the Caseless Caddis Larvae of the British Isles: With Notes on Their Ecology. Freshwater Biological Association Scientific Publication, 53: 1-134.

7. Edington, J.M. \& Hildrew, A.G. 1995. A Key To The Caseless Caddis Larvae of the British Isles With Notes On Their Ecology. Freshwater Biological Association Scientific Publication, 43: 1-91.

8. Flint, O.S.Jr. 1984. The genus Brachycentrus in North America, with a proposed phylogeny of the genera of Brachycentridae (Trichoptera). Smithsonian Contributions to Zoology, 398: 1-58.

9. García de Jalón, D. 1982. Los Trichoptera del río Lozoya. Boletín Asociación española Entomología, 5: 4158 .

10. Giudicelli, J. \& Orsini, A. 1987. Trichoptères de Corse, biogéographie, écologie et distribution des espèces dans les cours d'eau. Proceedings of the $5^{\text {th }}$ International Symposium on Trichoptera. (ed. by M. Bournaud and H. Tachet) pp. 325-329. Dr. W. Junk, Dordrecht, The Netherlands.

11. Google Earth, 2019. http://www.earth.google.com (Data accessed: March 2019).

12. Hickin N.E. 1942. Larvae Of The British Trichoptera. The Proceedings of the Royal Entomological Society of London Series A. General Entomology, 17: 16-17.

13. Hickin N.E. 1943. Larvae Of The British Trichoptera. The Proceedings of the Royal Entomological Society of London Series A. General Entomology, 18: 15-17.

14. Hickin N.E. 1948. Larvae Of The British Trichoptera. The Proceedings of the Royal Entomological Society of London Series A. General Entomology, 23: 54-56.

15. Hickin N.E. 1952. Larvae Of The British Trichoptera. The Proceedings of the Royal Entomological Society of London Series A. General Entomology, 27: 86-88.

16. Hickin N.E. 1954. Larvae Of The British Trichoptera. The Proceedings of the Royal Entomological Society of London Series A. General Entomology, 29: 89-92.

17. Hickin, N. E. 1967. Caddis larvae: larvae of the British Trichoptera. 1st edition, Fairleigh Dickinson Univ Press, Rutherford, $480 \mathrm{pp}$.

18. Hilsenhoff, W.L. 1985. The Brachycentridae (Trichoptera) of Wisconsin. Great Lakes Entomologist, 18: 149-154.

19. Kazanc1, N. \& Ertunc, O. 2010. Use of Simuliidae (Insecta, Diptera) species as indicators of aquatic habitat quality of Yeşilırmak River Basin (Turkey). Review of Hydrobiology, 3: $27-36$
20. Küçükbasmacı, İ. \& Kıyak, S. 2017. A study on the caddisfly fauna (Insecta: Trichoptera) of Kastamonu and a new species record for Turkey. Munis Entomology \& Zoology, 12: 486-499.

21. Lechthaler, W. \& Stockinger, W. 2005. Trichoptera: Key to Larvae from Central Europe (DVD).

22. Lechthaler, W. 2007. Trichoptera Families: Key to Larvae from Central Europe (CD).

23. Malicky, H. 2004. Atlas of European Trichoptera, second edition. Springer Dordrecht, The Netherlands, 359 pp.

24. Morse, J.C. (ed.). 2018. Trichoptera World Checklist. http://entweb.clemson.edu/database/trichopt/index.htm (Data Accessed: October 2018).

25. Mosely, M.E. 1930. Corsican Trichoptera. Eos-Revista Española Entomologia, 6: 147-184.

26. Pescador, M.L., Rasmussen, A.K. \& Harris, S.C. 1995 Identification manual for the caddisfly (Trichoptera) larvae of Florida. Florida Department of Environmental Protection, Tallahassee, Florida, USA, 186 pp.

27. Sipahiler, F. 2016. Two new species of Trichoptera (Psychomyiidae, Beraeidae) from Turkey. Nova Acta Científica Compostelana (Bioloxía), 23: 61-64.

28. Sipahiler, F. 2017a. Four new species of the genus Kelgena Mey from Turkey (Trichoptera: Limnephilidae, Chaetopterygini). Nova Acta Científica Compostelana (Bioloxía), 24: 13-20.

29. Sipahiler, F. 2017b. Descriptions of two new species of the genus Psilopteryx Stein from Turkey (Trichoptera, Limnephilidae, Chaetopterygini). Nova Acta Cientifica Compostelana (Bioloxía), 24: 69-73.

30. Sipahiler, F. 2018a. Three new species of caddisflies (Trichoptera Hydroptilidae, Leptoceridae) from Turkey and faunistic list for the Seyhan and Ceyhan rivers. Nova Acta Científica Compostelana (Bioloxía), 25: 37-43.

31. Sipahiler, F. 2018b. Studies on the males of the genus Philopotamus Leach in Turkey (Trichoptera, Philopotamidae). Nova Acta Cientifica Compostelana (Bioloxía), 25: 55-70.

32. Ulmer, G. 1909. Trichoptera. Pp. 1-326. In: Brauer, A. (ed) Die Süßwasserfauna Deutschlands. Eine Exkursionsfauna, Heft 5-6. Verlag Von Gustav Fischer, Jena, 326 pp.

33. Vieira-Lanero, R., González, M.A. \& Cobo, F. 1998. Descripción de la larva de Micrasema servatum (Navás, 1918) (Trichoptera, Brachycentridae). Graellsia, 54: 3-8.

34. Zamora-Muñoz, C. Alba-Tercedor, J. \& García de Jalón, D. 1995. The larvae of the genus Hydropsyche (Hydropsychidae; Trichoptera) and key for the identification of species of the Iberian Peninsula. Mitteilungen der Schweizerischen Entomologischen Gesellschaft, 68(1-2): 189-210. 